Note

\title{
Effects of Food Additives on Susceptibility of Gram Negative Bacteria Derived
}

\section{from Dry-Fermented Sausage}

\author{
Serjmyadag Dors ${ }^{1}$, Kenichiro ShImada ${ }^{2}$ and Mitsuo SeKIKAwA ${ }^{3 *}$ \\ ${ }^{I}$ The United Graduate School of Agricultural Sciences, Iwate University, Morioka, Iwate 020-8550, Japan \\ ${ }^{2}$ Department of Food Science, Obihiro University of Agriculture and Veterinary Medicine, Obihiro, Hokkaido 080-8555, Japan \\ ${ }^{3}$ Department of Animal and Food Hygiene, Obihiro University of Agriculture and Veterinary Medicine, Obihiro, Hokkaido 080-8555, \\ Japan
}

Received August 4, 2008; Accepted November 25, 2008

This study examined the effects of food additives on gram-negative bacteria. The food additives used included synthetic antioxidants (butylated hydroxyanisole, BHA, and butylated hydroxytoluene, BHT), a curing agent and lactic acid with or without a cell-free supernatant (CFS) containing antimicrobial compounds of Lactobacillus sakei D-1001. The gram-negative bacteria were selected from dry-fermented sausages and cultured with different food additives for $18 \mathrm{~h}$ in nutrient broth, and then another $24 \mathrm{~h}$ with or without CFS adjusted (at pH 6.0) to inactivate lactic acid or not adjusted (at pH 4.0). BHA (0.1\%) resulted in total viable cell inhibition following $18 \mathrm{~h}$ culture. A reduction in cell growth was observed in culture broths with $0.1 \%$ lactic acid and synthetic antioxidants at different concentrations. Furthermore, greater susceptibility of gram-negative bacteria could be obtained in 18+24-h cultures with combinations of selected food additives and antimicrobial compounds of Lactobacillus sakei D-1001, in a low pH environment depending on the lactic acid concentration.

Keywords: food additive, antimicrobial compounds, gram-negative bacteria

\section{Introduction}

Food additives are used extensively in fermented meat products and are involved in various reactions of the meat environment that contribute to the development of taste, texture, consistency, or color. In addition, specific additives used in fermented products have shown important multiple effects for extending shelf life, which is determined by both microbiological (spoilage) and chemical (oxidation and physical) deterioration, such as the production of lactic acid bacteria (LAB) and their antioxidants.

Numerous studies have reported on the spoilage of meat and fermented meat products by pathogenic gram-negative bacteria, including Escherichia coli (Glass. Kathleen et al., 1992; Ferreira et al., 2006) and Salmonella (Buchanan and Whiting, 1998; Escartin et al., 1999), which produce toxins and cause several diseases in humans (Doyle and Schoeni,

*To whom correspondence should be addressed.

E-mail: sekikawa@obihiro.ac.jp
1984; Padhye et al., 1992; Centers for Disease Control, 1995; Pearse et al., 2004). In addition, lipid oxidation in foods may also pose a human health risk (Pearson et al., 1983; Kubow, 1992). To minimize these risks, desirable bacteria that produce antibacterial compounds and food additives have been added to fermented meat products. There are many scientific reports about the positive effects of food additives such as antioxidants (Bozkurt and Erkmen, 2002; Ansorena and Astiasaran, 2004; Lee and Kunz, 2005; Bozkurt, 2006), curing agents (Noil et al., 1990; Olesen et al., 2004) and LAB as starter culture (de Vuyst and Vandamme, 1994; Coffey et al., 1998; Niku-Paavola et al., 1999; Lucke, 2000; Kalalou et al., 2004) in fermented meat products. However, their correlation to such effects as well as the nature of their specific positive actions in the fermented products are not yet clear, especially against food pathogenic gram-negative bacteria. Gram-negative bacteria are highly resistant to foreign molecules such as antimicrobial compounds of LAB (Nikaido, 1989; Gao et al., 1999) due to an effective barrier function of their outer mem- 
branes (Nikaido, 1994), which are absent in gram-positive bacteria.

The aim of this study was to establish a method for reducing the number of gram-negative bacteria either through the use of food additives like lactic acid, butylated hydroxyanisole (BHA), BHA/butylated hydroxytoluene (BHT) and the curing agent alone or in combination with antimicrobial compounds produced by LAB.

\section{Materials and Methods}

Food additives Synthetic antioxidants, BHA and BHT, were purchased from MP Biomedicals (Vannes, France) and Nacalai Tesque (Kyoto, Japan), respectively. Lactic acid was obtained from Kanto Chemical (Tokyo, Japan). The curing agent (a mixture containing 5\% $\mathrm{NaNO}_{2}, 10 \% \mathrm{KNO}_{3}$ and $85 \% \mathrm{NaCl}$ ) was obtained from Chiyoda Industry Co. (Tokyo, Japan).

Experimental design Sterile nutrient broths (Merck, Germany) were prepared with each of the following: 3 BHA concentrations $(0.01 \%, 0.05 \%$, and $0.1 \%)$, BHA/BHT combination $(0.01 \% \mathrm{BHA}+0.01 \% \mathrm{BHT})$, lactic acid at two concentrations $(0.05 \%$ and $0.1 \%)$, the curing agent $(0.2 \%)$ or a negative control. A gram-negative bacterial suspension was prepared as described below and was inoculated in each broth to a final concentration of $1 \%$ and then incubated at $30^{\circ} \mathrm{C}$ for $18 \mathrm{~h}$. Each culture broth was then divided into three 9-ml portions and $1 \mathrm{ml}$ cell-free supernatant (CFS) prepared as described below was added to two portions and incubated for another $24 \mathrm{~h}$ at $30^{\circ} \mathrm{C}$; no CFS was added to the third portion. The two portions with CFS were used to determine the combined effects of food additives and CFS at different $\mathrm{pH}$ on gram-negative bacteria isolated from dry-fermented sausage. After the final incubation, viable cell counts of gramnegative bacteria were enumerated using the direct plating method on MacConkey agar. Immediately after incubation, $\mathrm{pH}$ values were also measured with a $\mathrm{pH}$ meter (HM-5S, TOA Electronics, Tokyo, Japan). These experiments were performed in triplicate.

Preparation of bacterial inoculum Dry-fermented sausage $(10 \mathrm{~g})$ recovered at the end of processing was analyzed for the presence of gram-negative bacteria. A homogenized sample (1:10 dilution in sterile saline) was used to prepare serial dilutions $\left(10^{-1}-10^{-3}\right)$ using sterile saline and 1-ml aliquots of each dilution were incubated with DHL agar (Merck, Darmstadt, Germany). After aerobic incubation of the plates for $24 \mathrm{~h}$ at $37^{\circ} \mathrm{C}, 9$ colonies were selected from the plates containing $2.9 \times 10^{2}$ colony counts and subcultured onto nutrient agar (Difco, Detroit, MI, USA). Then, cell morphology, gram reaction (Gram stain B\&M, Merck), growth on MacConkey agar (Eiken, Tokyo, Japan) and gas production in brilliant green lactose bile broth (Eiken, Tokyo, Japan) were quantified for gram-negative bacteria selection. Bacteria that are rod-shaped, gram-negative, gas producing and pinkish in color on MacConkey agar were selected and stored in nutrient broth supplemented with $30 \%$ glycerol at $-20^{\circ} \mathrm{C}$ until further analysis. Just before analysis, frozen cultures were activated in fresh nutrient broth $(1 \%)$ at $37^{\circ} \mathrm{C}$ for $24 \mathrm{~h}$ and stored at $4{ }^{\circ} \mathrm{C}$. To determine numbers of colony-forming units (CFU), diluted culture was plated on MacConkey agar and incubated at $37^{\circ} \mathrm{C}$ for $24 \mathrm{~h}$. The refrigerated stationary-phase cells were diluted to a cell density of around $8 \log \mathrm{CFU} / \mathrm{ml}$ and used as the inoculum.

Preparation of crude CFS from LAB L. sakei D-1001 from MMF-161 commercial starter culture (San-ei Sucrochemical Co., Chita, Japan) was cultivated in $100 \mathrm{ml}$ MRS broth at $30^{\circ} \mathrm{C}$ for $72 \mathrm{~h}$. CFS, which contained antimicrobial compounds from LAB (Daeschel, 1989), was obtained by centrifugation $\left(10,000 \times \mathrm{g}, 20 \mathrm{~min}, 4^{\circ} \mathrm{C}\right)$ and then filtrated through a $0.22-\mu \mathrm{m}$ pore-size filter (Corning, NY, USA). To determine the effect of $\mathrm{pH}$ on the gram-negative bacteria cultured with various additives in nutrient broth, we used CFS at a non-adjusted $\mathrm{pH}$ of 4.0 and an adjusted $\mathrm{pH}$ of 6.0 with the addition of $10 \mathrm{~N} \mathrm{NaOH}$; increasing $\mathrm{pH}$ mitigates the antimicrobial effects of organic acids produced in the Lactobacillus culture.

Statistical analysis Enumerated populations of gramnegative bacteria were transformed into $\log _{10} \mathrm{CFU} / \mathrm{ml}$ for data analysis. Analysis of variance (ANOVA) was performed on the data, followed by Turkey's test when significant differences of $p<0.05$ and $p<0.01$ were observed. SAS (SAS Institute, Cary, NC, USA) was used for statistical analysis.

\section{Results}

pH Changes in $\mathrm{pH}$ of broth cultures inoculated with gram-negative bacteria and different food additives are shown in Table 1. After the initial 18-h culture, $\mathrm{pH}$ of the culture broths with BHA at different concentrations ranged from $6.19 \pm 0.16$ to $7.08 \pm 0.03$. For broths containing $0.05 \%$ or $0.1 \%$ lactic acid or the curing agent, $\mathrm{pH}$ was $5.09 \pm 0.01$, $4.28 \pm 0.02$ and $6.43 \pm 0.03$, respectively. Compared to the control, significantly lower $\mathrm{pH}(p<0.05)$ was observed in culture broths with lactic acid, while significantly higher $\mathrm{pH}$ $(p<0.05)$ was observed in culture broths with $0.1 \%$ BHA. Following the additional 24-h culture, $\mathrm{pH}$ changed depending on the presence of CFS. A significant reduction in $\mathrm{pH}(p$ $<0.01$ ) was observed after the addition of CFS at $\mathrm{pH} 4.0$, compared to both broths with and without CFS at $\mathrm{pH}$ 6.0. In addition, all culture broths decreased $\mathrm{pH}$ from $4.13 \pm 0.03$ to $4.78 \pm 0.03$ after the addition of CFS at $\mathrm{pH} 4.0$. Culture broths with or without $\mathrm{CFS}$ at $\mathrm{pH} 6.0$ in combination with 
Table 1. $\mathrm{pH}$ of the broth cultures inoculated with gram-negative bacteria and different additives (mean $\pm \mathrm{SD}$ for $\mathrm{n}=3$ ).

\begin{tabular}{ccccc}
\hline Broth & $18 \mathrm{~h}$ & $\begin{array}{c}18+24 \mathrm{~h} \text { with } \\
\text { CFS at pH 4.0 }\end{array}$ & $\begin{array}{c}18+24 \mathrm{~h} \text { with } \\
\text { CFS at pH } 6.0\end{array}$ & $\begin{array}{c}18+24 \mathrm{~h} \\
\text { without CFS }\end{array}$ \\
\hline control & $6.28 \pm 0.12^{\mathrm{b}}$ & $4.74 \pm 0.05^{\mathrm{c}}$ & $6.20 \pm 0.10^{\mathrm{b}}$ & $7.09 \pm 0.26^{\mathrm{a}}$ \\
$0.01 \%$ BHA & $6.19 \pm 0.16^{\mathrm{b}}$ & $4.64 \pm 0.04^{\mathrm{c} *}$ & $6.04 \pm 0.08^{\mathrm{b}}$ & $6.70 \pm 0.10^{\mathrm{a} *}$ \\
$0.02 \%$ BHA/BHT & $6.20 \pm 0.10^{\mathrm{b}}$ & $4.65 \pm 0.03^{\mathrm{c} *}$ & $6.08 \pm 0.04^{\mathrm{b}}$ & $6.78 \pm 0.18^{\mathrm{a}}$ \\
$0.05 \%$ BHA & $6.63 \pm 0.56^{\mathrm{a}}$ & $4.60 \pm 0.00^{\mathrm{b} *}$ & $5.80 \pm 0.08^{\mathrm{a} *}$ & $6.28 \pm 0.29^{\mathrm{a} *}$ \\
$0.1 \%$ BHA & $7.08 \pm 0.03^{\mathrm{a} *}$ & $4.59 \pm 0.01^{\mathrm{c} *}$ & $6.54 \pm 0.02^{\mathrm{b} *}$ & $7.12 \pm 0.06^{\mathrm{a}}$ \\
$0.1 \%$ lactic acid & $4.28 \pm 0.02^{\mathrm{b} *}$ & $4.13 \pm 0.03^{\mathrm{c} *}$ & $4.60 \pm 0.05^{\mathrm{a} *}$ & $4.27 \pm 0.03^{\mathrm{b} *}$ \\
$0.05 \%$ lactic acid & $5.09 \pm 0.01^{\mathrm{c} *}$ & $4.43 \pm 0.03^{\mathrm{d} *}$ & $5.67 \pm 0.06^{\mathrm{b} *}$ & $6.07 \pm 0.21^{\mathrm{a} *}$ \\
$0.2 \%$ curing agent & $6.43 \pm 0.03^{\mathrm{b}}$ & $4.78 \pm 0.03^{\mathrm{c}}$ & $6.37 \pm 0.03^{\mathrm{b} *}$ & $7.28 \pm 0.09^{\mathrm{a} *}$ \\
\hline
\end{tabular}

* Means significantly different in same column with respect to the control $(p<0.05)$.

${ }^{\mathrm{a}-\mathrm{d}}$ Means in the same row with superscript letters in common are significantly different $(p<0.01)$.

BHA at various concentrations resulted in $\mathrm{pH}$ ranges of 5.80 \pm 0.08 to $6.54 \pm 0.02$ and $6.28 \pm 0.29$ to $7.12 \pm 0.06$, respectively. The $\mathrm{pH}$ of culture broth containing $0.05 \%$ lactic acid with and without CFS at pH 6.0 was $5.67 \pm 0.06$ and $6.07 \pm$ 0.21 , respectively, while that of culture broth containing $0.1 \%$ lactic acid with and without CFS was $4.60 \pm 0.05$ and 4.27 \pm 0.03 , respectively. The culture broths inoculated with the curing agent with or without $\mathrm{CFS}$ at $\mathrm{pH} 6.0$ had the $\mathrm{pH}$ of 6.37 \pm 0.03 and $7.28 \pm 0.09$, respectively.

Effects of different food additives in 18-h cultures The populations of gram-negative bacteria in nutrient broths containing the synthetic antioxidant, lactic acid and curing agent are presented in Table 2. For treatments with $0.1 \%$ lactic acid, $0.01 \%$ or $0.05 \%$ BHA and $0.02 \%$ BHA/BHT, growth of gram-negative bacteria was significantly $(p<0.05)$ reduced by approximately $4.8,1,1.3$ and $1.5 \log$ units, respectively, compared to the controls. For $0.1 \%$ BHA alone, growth of gram-negative bacteria was completely inhibited in the $18-\mathrm{h}$ culture at $\mathrm{pH} 7.08$. Incubated culture broths with $0.2 \%$ curing agent and $0.05 \%$ lactic acid showed no significant differences in viable cell counts, compared to the control without additives.

Effect of CFS in 18+24-h culture The effects of food additives on the susceptibility of gram-negative bacteria to antimicrobial compounds from L. sakei D-1001 were expressed as the log-reduction of viable cell counts (Table 2). Analysis of this data revealed significant differences among the 18+24-h cultures $(p<0.01)$, depending on the addition of CFS. When CFS at pH 4.0 was added, a substantial reduction in gram-negative bacteria was observed in all culture broths including the control; no viable cells were detected following the use of CFS at $\mathrm{pH} 4.0$ in cultures with either $0.05 \% \mathrm{BHA}$ or $0.02 \%$ BHA/BHT. The viable cell count was markedly reduced to $1.02 \pm 0.03 \log$ units in cultures with a combination

Table 2. Viable counts of gram-negative bacteria in broth cultures with different additives (mean $\log _{10} \mathrm{CFU} / \mathrm{ml} \pm \mathrm{SD}$ for $\mathrm{n}=3$ ).

\begin{tabular}{ccccc}
\hline Broth & $18 \mathrm{~h}$ & $\begin{array}{c}18+24 \mathrm{~h} \text { with } \\
\text { CFS at pH } 4.0\end{array}$ & $\begin{array}{c}18+24 \mathrm{~h} \text { with } \\
\text { CFS at pH } 6.0\end{array}$ & $\begin{array}{c}18+24 \mathrm{~h} \\
\text { without CFS }\end{array}$ \\
\hline control & $8.57 \pm 0.15^{\mathrm{a}}$ & $6.77 \pm 0.32^{\mathrm{b}}$ & $8.90 \pm 0.10^{\mathrm{a}}$ & $9.07 \pm 0.21^{\mathrm{a}}$ \\
$0.01 \%$ BHA & $7.60 \pm 0.30^{\mathrm{a} *}$ & $1.02 \pm 0.03^{\mathrm{b} *}$ & $8.17 \pm 0.21^{\mathrm{a} *}$ & $8.20 \pm 0.36^{\mathrm{a} *}$ \\
$0.02 \%$ BHA/BHT & $7.07 \pm 0.32^{\mathrm{b} *}$ & $\mathrm{ND}$ & $8.20 \pm 0.10^{\mathrm{a} *}$ & $8.10 \pm 0.26^{\mathrm{a} *}$ \\
$0.05 \%$ BHA & $7.23 \pm 0.71^{\mathrm{ab} *}$ & $\mathrm{ND}$ & $7.80 \pm 0.36^{\mathrm{a} *}$ & $6.37 \pm 0.21^{\mathrm{b} *}$ \\
$0.1 \%$ BHA & $\mathrm{ND}$ & $\mathrm{ND}$ & $\mathrm{ND}$ & $\mathrm{ND}$ \\
$0.1 \%$ lactic acid & $3.77 \pm 0.95^{\mathrm{a} *}$ & $\mathrm{ND}$ & $\mathrm{ND}$ & $4.37 \pm 0.51^{\mathrm{a} *}$ \\
$0.05 \%$ lactic acid & $8.23 \pm 0.06^{\mathrm{a}}$ & $4.00 \pm 0.69^{\mathrm{b} *}$ & $8.53 \pm 0.12^{\mathrm{a}}$ & $8.73 \pm 0.32^{\mathrm{a}}$ \\
$0.2 \%$ curing agent & $8.67 \pm 0.32^{\mathrm{a}}$ & $3.20 \pm 1.57^{\mathrm{b} *}$ & $8.87 \pm 0.25^{\mathrm{a}}$ & $9.10 \pm 0.10^{\mathrm{a}}$ \\
\hline
\end{tabular}

$\mathrm{ND}$, no detection $(<30 \mathrm{CFU} / \mathrm{mL})$.

* Means significantly different in the same column, compared to the control $(p<0.05)$.

${ }^{\mathrm{a}, \mathrm{b}}$ Means in the same row with different letters are significantly different $(p<0.01)$. 
of $0.01 \% \mathrm{BHA}$ and CFS at $\mathrm{pH} 4.0$. In contrast, the viable cell counts of gram-negative bacteria from 18-h cultures were increased in $18+24-\mathrm{h}$ culture broths regardless of the presence or absence of CFS at pH 6.0, except for culture broth with $0.05 \%$ BHA alone, which had a slightly decreased viable cell count.

The viable cell count was reduced to $3.77 \pm 0.95 \log$ units by $0.1 \%$ lactic acid in the 18 -h culture and then was slightly increased to $4.37 \pm 0.51 \log$ units after the additional 24-h culture without CFS. For this additive, the gram-negative bacterial population was absent when CFS was added at either $\mathrm{pH}$. On the other hand, when a lower concentration of lactic acid was used, CFS at $\mathrm{pH} 4.0$ reduced the viable cell count from $8.23 \pm 0.06 \log$ units to $4.0 \pm 0.69 \log$ units (a decrease of approximately $4.23 \mathrm{log}$ units). In contrast, the same additive with or without $\mathrm{CFS}$ at $\mathrm{pH} 6.0$ showed an increase in the viable cell count; a similar trend was seen for cultures with the curing agent.

\section{Discussion}

This study examined the effects of various food additives on gram-negative bacteria in broth. Gram-negative bacteria were isolated from dry-fermented sausages made without starter culture. The fermented meat products might be spoiled by pathogens without a heating step to control pathogen populations (Rodel, 1992; Gill and Landers, 2003). However, in many cases of spoilage, bacteria can be reduced in number, either by inhibition or elimination by various manufacturing methods including the use of LAB in fermentation (Takeo et al., 1994; Coffey et al., 1998; Gonzalez and Diez, 2002; Kalalou et al., 2004). In this study, L. sakei was selected because it 1) is more competitive than other lactobacilli, 2) is most commonly found in dry-fermented sausages (Rantsiou and Cocolin, 2006), 3) has a shorter lag phase, 4) has a higher maximum growth rate, and 5) has higher final cell density (Dossmann et al., 1996), which all contribute to the hygienic quality of meat products by producing various antimicrobial compounds including organic acid, hydrogen peroxide, carbon dioxide, diacetyl and high molecular mass compounds like bacteriocins towards undesirable bacteria such as gram-positive bacteria (Mataragas et al., 2003). However, Tantillo et al. (2002) reported that gram-negative bacteria were resistant to antimicrobial activity of $L$. sakei. Lactic acid produced by LAB in sausage fermentation reduces $\mathrm{pH}$ at which point it has a preservative effect; $\mathrm{pH}$ values below 5.2 in dry-fermented sausage are favorable for preservation and its hygienic stability (Leistner, 1995). Among all culture additives tested in this study, culture broths with $0.1 \%$ lactic acid showed the lowest $\mathrm{pH}$. A pronounced decrease in $\mathrm{pH}$ was observed in all culture broths incubated with CFS at
pH 4.0.

Increasing BHA concentration demonstrated a predictable trend in decreasing viable cell counts. BHA has antibacterial effects; however, $0.1 \% \mathrm{BHA}$, which is lethal and effective at total inhibition of gram-negative bacteria, currently exceeds the legal limitations for use in food products (FDA: http://www.cfsan.fda.gov/ dms/opa-appa.html). However, a combination of this synthetic antioxidant at lower concentrations $(0.01 \%-0.05 \%)$ with $\mathrm{CFS}$ at $\mathrm{pH} 4.0$ has the ability to suppress gram-negative bacteria. In this study, reduction in bacterial number was observed for combinations of CFS at $\mathrm{pH} 4.0$ with this synthetic antioxidant even at the lowest concentration of $0.01 \%$. It has previously been reported that the inhibitory effect of this synthetic antioxidant on pathogenic bacteria is due to its ability to disrupt cytoplasmic membranes of cells (Branen et al., 1980; Degre and Sylvestre, 1983; Degre et al., 1983). To our knowledge, this is the first report on the effects of a combination of BHA and CFS against gram-negative bacteria.

In general, lactic acid is produced by LAB in fermented meat products and produces primarily antimicrobial effects against spoilage bacteria (Daeschel, 1989). In our study, the effects of changes in the lactic acid concentration alone or in combination with the addition of CFS on gram-negative bacteria in broth were examined. For $0.1 \%$ lactic acid alone, viable cell counts were markedly reduced following $18 \mathrm{~h}$ culture, but increased after an additional $24 \mathrm{~h}$ culture. In contrast, for a combination of $0.1 \%$ lactic acid and CFS, no viable cells were observed, and for a combination of $0.05 \%$ lactic acid with CFS at pH 4.0 only, a reduction in viable cells was observed. Furthermore, we observed that control cultures with CFS at $\mathrm{pH} 4.0$ were also more efficient than those with or without CFS at $\mathrm{pH}$ 6.0. These findings confirmed results of several reports on the inhibitory effects of lactic acid (Van Netten et al., 1995; Pipek et al., 2005) and the fact that lactic acid increases the outer membrane permeability of gram-negative bacteria (Alakomi et al., 2000).

Curing agents are commonly used in dry-fermented sausage to aid in flavor development and to prevent lipid rancidity (Noil et al., 1990; Olesen et al., 2004). Curing agent concentration in this study was fixed at $0.2 \%$ because of results in our previous experiment (Mikami et al., 2004). In this study, no antimicrobial effect was seen with $0.2 \%$ curing agent alone, which is similar to the control without any additives. However, the combination of $0.2 \%$ curing agent with CFS at $\mathrm{pH} 4.0$ appears to prevent gram-negative bacteria growth. Leroy et al. (1999) suggested that nitrite, which is a component of the curing agent, has a synergistic action with lactic acid that is commonly found in CFS (Lindgren and Dobrogosz, 1990). This explains our observation that gram- 
negative bacteria are susceptible to the curing agent when combined with CFS at a high lactic acid concentration.

In this study, combinations of antimicrobial treatments at $\mathrm{pH}$ at $4.78 \pm 0.03$ or less were effective at inhibiting gramnegative bacteria derived from dry-fermented sausage compared with using single treatments, except in the case of $0.1 \%$ BHA, which alone inhibited all viable cells. These results partially agree with those of Leistner et al. (1995), which showed that two or more antimicrobial agents acting synergistically at suboptimal levels are more effective than each of them alone at the optimal level.

Therefore, using food additives can increase gram-negative bacteria susceptibility to antimicrobial compounds of $L$. sakei D-1001, but only in low $\mathrm{pH}$ environments that depend on the lactic acid concentration. In addition, food additives at concentrations permitted by the FDA, in combination with antimicrobial compounds of LAB can be useful in devising control strategies for pathogenic gram-negative bacteria in acidic foods such as fermented meat products. Recently, naturally occurring antioxidants are being replaced by synthetic antioxidants because they exhibit similar antioxidant potency (Ramarathnam et al., 1995; Zein, 2000; Bozkurt, 2006). Additional studies are needed to investigate the efficiency of combining natural antioxidants and LAB compounds on gram-negative bacteria.

\section{References}

Alakomi, H.L., Skytta, E., Saarela, M., Mattila-Sandholm, T., Latva-Kala, K. and Helander., I.M. (2000). Lactic acid permeabilizes gram negative bacteria by disrupting the outer membrane. Appl. Environ. Microbiol., 66, 2001-2005.

Ansorena, D. and Astiasaran, I. (2004). The use of linseed oil improves nutritional quality of the lipid fraction of dry-fermented sausages. Food Chemist., 87, 69-74.

Bozkurt, H. and Erkmen, O. (2002). Effects of starter cultures and additives on the quality of Turkish style sausage (sucuk). Meat Sci., 61, 149-156.

Bozkurt, H. (2006). Utilization of natural antioxidants: Green tea extract and Thymbra spicata oil in Turkish dry-fermented sausage. Meat Sci., 73, 442-450.

Branen, A.L., Davidson, P.M. and Katz, B. (1980). Antimicrobial properties of phenolic antioxidants and lipids. Food Technol., 34, 42-53.

Buchanan, R.L. and Whiting, R.C. (1998). Risk assessment: a means for linking HACCP plans and public health. J. Food Prot., 61, 1531-1534.

Centers for Disease Control. (1995). Escherichia coli O157:H7 outbreak linked to commercially distributed dry-cured salamiWashington and California. 1994. Morbid. Mortal. Weekly Rep., 44, 157-160.
Coffey, A., Ryan, M., Ross, R.P., Hill, C., Arendt, E. and Schwarz, G. (1998). Use of a broad-host range bacteriocin-producing Lactococcus lactis transconjugant as an alternative starter for salami manufacture. Int. J. Food Microbiol., 43, 231-235.

Daeschel, M.A. (1989). Antimicrobial substances from lactic acid bacteria for use food preservatives. Food Technol., 43, 164-167.

Degre, R. and Sylvestre, M. (1983). Effect of butylated hydroxyanisole on the cytoplasmic membrane of Staphylococcus aureus Wood 46. J. Food Prot., 46, 206-209.

Degre, R., Ishaque, M. and Sylvestre, M. (1983). Effect of butylated hydroxyanisole on the electron transport system of Staphylococcus aureus Wood 46. Microbios, 37, 7-13.

de Vuyst, L. and Vandamme, E.J. (1994). Antimicrobial potential of lactic acid bacteria, p. 91-142. In: L. de Vuyst and E. J. Vandamme (ed.), Bacteriocins of lactic acid bacteria: microbiology, genetics and applications. Blackie Academic and Professional, London, United Kingdom.

Dossmann, M.U., Vogel, R.F. and Hammes, W.P. (1996). Mathematical description of the growth of Lactobacillus sakei and Lactobacillus pentosus under conditions prevailing in fermented sausage. Appl. Microbiol. Biotechnol., 46, 334-339.

Doyle, M.P. and Schoeni, J.L. (1984). Survival and growth characteristics of Escherichia coli associated with hemorrhagic colitis. Appl. Environ. Microbiol., 48, 855- 856.

Escartin, E.F., Castillo, A., Hinojosa-Puga, A. and Saldana-Lozano, L. (1999). Prevalence of Salmonella in chorizo and its survival under different storage temperatures. Food Microbiol., 16, 479-486.

Ferreira, V., Barbosa, J., Vendeiro, S., Mota, A., Silva, F., Monteiro, M.J., Hogg, T., Gibbs, P. and Teixeira., P. (2006). Chemical and microbiological characterization of alheira: A typical Portuguese fermented sausage with particular reference to factors relating to food safety. Meat Sci., 73, 570-575.

Gao, Y., Van Belkum, M.J. and Stiles, M.E. (1999). The outer membrane of gram negative bacteria inhibits antibacterial activity of brochocin-C. Appl. Environ. Microbiol., 65, 4329-4333.

Gill, C.O. and Landers, C. (2003). Microbiological effects of carcass decontaminating treatments at four beef packing plants. Meat Sci., 65, 1005-1011.

Glass. Kathleen A., Loeffelholz, Jodi M., Patrick Ford, J. and Doyle, Michael P. (1992). Fate of Escherichia coli O157:H7 as affected by $\mathrm{pH}$ or sodium chloride and in fermented, dry sausage. Appl. Environ. Microbiol., 58, 2513-2516.

Gonzalez, B. and Diez, V. (2002). The effect of nitrite and starter culture on microbiological quality of "chorizo" a Spanish dry cured sausage, Meat Sci., 60, 295-298.

Kalalou, I., Faid, M. and Ahami, T.A. (2004). Improving the quality of fermented camel sausage by controlling undesirable microorganisms with selected lactic acid bacteria. Int. J. Agric. Biol., 6, 447-451. 
Kubow, S. (1992). Routes of formation and toxic consequences of lipid oxidation products in foods. Free Rad. Biol. Med., 12, 63-81.

Lee, J. and Kunz, B. (2005). The antioxidant properties of baechukimchi and freeze-dried kimchi-powder in fermented sausages. Meat Sci., 69, 741-747.

Leistner, L. and Gorris, L. G. M. (1995). Food preservation by hurdle technology. Trends Food Sci. Technol., 6, 41-46.

Leistner, L. (1995). Stable and safe fermented sausages worldwide, p. 160-175. In: Campbell - Platt, G., and P. E. Cook (ed.), Fermented meats. Blackie Academic and Professional, London, United Kingdom.

Leroy, F. and de Vuyst, L. (1999). The presence of salt and curing agent reduces bacteriocin production by Lactobacillus sakei CTC 494, a potential starter culture for sausage fermentation. Appl. Environ. Microbiol., 65, 5350-5356.

Lindgren, S.E. and Dobrogosz, W.J. (1990). Antagonistic activities of lactic acid bacteria in food and feed fermentations. FEMS Microbiol. Rev., 7, 149-163.

Lucke, F.K. (2000). Utilization of microbes to process and preserve meat. Meat Sci., 56, 105-115.

Mataragas, M., Drosinos, E.H. and Metaxopoulos, J. (2003). Antagonistic activity of lactic acid bacteria against Listeria monocytogenes in sliced cooked cured pork shoulder stored under vacuum or modified atmosphere at $4 \pm 20^{\circ} \mathrm{C}$. Food Microbiol., 20, 259-265.

Mikami, M., Serjmyadag, D., Shimada, K. and Sekikawa, M. (2004). Production and some properties of fermented sausages inoculated with mould. Animal Sci. Agri. Hokkaido, 46, 71-78.

Van Netten, P., Mossel, D.A.A. and Huis Int Veld, J. (1995). Lactic acid decontamination of fresh pork carcasses: a pilot plant study. Int. J. Food Microbiol., 25, 1-9.

Nikaido, H. (1989). Outer membrane barrier as a mechanism of antimicrobial resistance. Antimicrob. Agents Chemother, 33, 1831-1836.

Nikaido, H. (1994). Prevention of drug access to bacterial targets: permeability barriers and active efflux. Science, 264, 382-388.

Niku-Paavola, M. L., Laitila, A., Mattila-Sandholm, T. and Haikara, A. (1999). New types of antimicrobial compounds produced by Lactobacillus plantarum. J. Appl. Microbiol., 86, 29-35.

Noil, P., Briand, E. and Dumont, J.P. (1990). Role of nitrite in fla- vour development in uncooked cured meat products: Sensory assessment. Meat Sci., 28, 1-8.

Olesen. P. T., Meyer, A.S. and Stahnke, L.H. (2004). Generation of flavour compo the influence of curing ingredients, Staphylococcus starter culture and ripening time. Meat Sci., 66, 675-687.

Padhye, N.V. and Doyle, M.P. (1992). Escherichia coli O157:H7: epidemiology, pathogenesis and methods for detection in food. $J$. Food Prot., 55, 555-565.

Pearse, R.A., Bolton, D.J., Sheridan, J.J., McDowell, D.A., Blair, I.S. and Harrington, D. (2004). Studies to determine the critical control points in pork slaughter hazard analysis and critical control point systems. Int. J. Food Microbiol., 90, 331-339.

Pearson, A.M., Gray, J.I., Wolzak, A.M. and Horenstein, N.A. (1983). Safety implications of oxidized lipids in muscle foods. Food Technol., 37, 121-129.

Pipek, P., Houska, M., Hoke, K., Jelenikova, J., Kyhos, K. and Sikulova, M. (2005). Decontamination of pork carcasses by steam and lactic acid. J. Food Engineer., 74, 224-231.

Ramarathnam, N., Osawa, T., Ochi, H. and Kawakishi, S. (1995). The contribution of plant food antioxidants to human health. Trends Food Sci. Technol., 6, 75-82.

Rantsiou, K. and Cocolin, L. (2006). New developments in the study of the microbiota of naturally fermented sausages as determined by molecular methods: a review. Int. J. Food Microbiol., 108, 255-267.

Rodel, W. (1992). Measurement magnitudes and transportable measuring instruments for in-factory quality control. Fleischwirtsch. Int., 4, 16-24.

Takeo, K., Umeyuki, D., Yukiko, Y., Masayuki, M. and Ryo. N. (1994). Isolation of psychrotrophic lactic acid bacteria, and its application for fermented meat products. Nippon Shokuhin Kagaku Kogaku Kaishi, 41, 108-115.

Tantillo, M.G.., Di, P.A. and Novello, L. (2002). Bacteriocin producing Lactobacillus sakei as starter culture in dry sausages. New Microbiol., 25, 45-49.

Zein, R. (2000). Utilization of mango seed kernels as a source of natural antioxidants. J. Agric. Sci., Mansoura University, 25, 7981-7994.

\section{URL Cited}

i) http://www.cfsan.fda.gov/ dms/opa-appa.html 